\title{
Trend in Household Expenditures in Albania
}

\author{
Ruzhdie Bici, Dr. \\ Albana Hashorva, Prof.Dr. \\ University of Tirana, Albania
}

Doi: 10.19044/esj.2018.v14n5p150 URL:http://dx.doi.org/10.19044/esj.2018.v14n5p150

\begin{abstract}
In Albania almost 50\% of the household expenditures go for food. The levels of the food have change by years but still have a considered weight in household budget. The study shows the trend and the significant factors that influence the food and non food consumption for different economic levels of the households in Albania. Household composition, geographic characteristics and other material deprivation dimensions have an important impact to the consumption trend and household wellbeing. The data refers to the Living Standard Measurement Survey (LSMS), which measure poverty through expenditures method. It is a multidimensional survey and gives us the possibility to have multi indicators and also disaggregate and test the relationship and influence. This paper shows the trend by household size, for different regions, the typology of the household and other socio-economic factors that may influence the food and non food expenditures trend. It is used the descriptive analyses and quintile regression of different foods level by different factors. The calculations are done using SPSS and Stata.
\end{abstract}

Keywords: Consumption, food expenditures, quintile, regression, poverty

\section{Introduction}

During years the economic situation in Albania has changed. These changes have influence also the household life and situation. In Albania 14.3 $\%$ of the population are poor and $2.3 \%$ are extreme poor (Instat, 2013). Till now in Albania is used consumption for measure of household welfare, poverty and inequality. Almost $50 \%$ of the total household expenditure goes for buying food products (Bici, 2016). Expenditures for food play an important role for development countries. Analyses the consumption also make possible to measure utility function of individuals (Attanasio and Pistaferri, 2016). But to measure the utility we need a deeper analyze and more focused on this specific topic and also we have to take in to the consideration prices. The consumption for food have different trend by years and is different for 
household characteristics. The total expenditures influence the food and non food part. Normally for different economic levels of the individuals (measure through quintile) the trend on the expenditures changed. To the bottom, individuals are more focused to spend for food and to the top the individuals tend to spend more for luxury product. There are different factors related with the trend on expenditures like household composition, living condition or individual characteristics that influence the trend on consumption. This paper presents the function of food and non food consumption based on income/expenditures and other influenced factors.

\section{Methodology}

This research is based on Living Standard Measurement Survey (LSMS) data. The poverty in Albania is measured through consumption as a more aquarate measure. This survey for the first time is conducted in 2002 and after every three years. The main objective of LSMS is measure poverty and inequality and other characteristics that may influence the significant difference for different groups. It is used the descriptive analyses and also the quintile regression to test the difference of a set of variables that influence the lowest $10 \%$ and the highest $10 \%$ of the consumption pattern. The influence is supposed that are different for food purpose and non food products. There are cross sectional data and the model is constructed by LSMS 2012 data. The LSMS have a variety of variables produced that lied to higher rates of disaggregation and the only source for poverty and inequality measure. As we are interested to see the influence factors by different economic level of the individuals is used the division of food by quintile or quintile regression. Also other surveys and other source related with household expenditures are used. The data are produced in SPSS version 20 and Stata version 12.

\section{Household expenditure in Albania, methodology}

Household consumption is considered to be measured more accurately than income due household hesitate to declare their income. Evaluation of poverty based on a multidimensional definition of poverty and not only deprivation of income or consumption, poverty is also defined in connection with not appropriate a series of arrangement of social care that are unrelated with income, such as education, health, household size, using of basic services and infrastructure.

Extreme Poverty: The food poverty line is the level of per capita expenditure per month, necessary for an individual to take the minimum amount of calories in one place by age and sex (taken in 2288 calories a day) 2 .

${ }^{2}$ http://siteresources.worldbank.org/PGLP/Resources/povertymanual_ch3.pdf 
Non food expenditures include the rest of expenditures that are used by households not for the food purpose.

In the following material are treated on the theoretical concepts and types of poverty indicators, influential factors and how and when displaying the characteristics of poverty. The study aims to study the relation of per capita consumption depending on a set of explanatory variables that are thought to have a statistically significant impact and are defined as influential factors in extreme poverty. Cross-sectional data means that have been collected from a sample of individuals, families at a time, in our case LSMS 2012.

The Engel method analyzed by Bici, (2016) shows how the trend on food is related with total household budget of Albania. Different researchers have proposed different regressions model showing this relationship. You (2003), have used the linear relationship of food with income. $\mathrm{Y}_{\mathrm{ij}}=\alpha+\beta \mathrm{X}_{\mathrm{ij}}+\mathrm{u}_{\mathrm{ij}}$

We use as depended variable $\mathrm{Y}_{\mathrm{ij}}$ the food expenditure and as $\mathrm{X}_{\mathrm{ij}}$ total household expenditures and other socio-economic variables. The same model is supposed to give also the relationship for the non food trend. The expectations on the coefficients are supposed to be different.

Betti (2000) shows the non linear relationship between the food and income. Also many authors have analyzed the trend on food as non linear relationship (Ahmed et al., 2012; Dawoud, Seham D. Z.,2013; Working, 1943; Leser, 1963). $\ln Y_{i j}=\alpha+\beta \ln X_{i j}+u_{i j}$

Koenker and Hallock (2001) state that quintile regression can be applied to a number of fields such as biomedicine and economics and provide an example about how to use quintile regression to explore Engel curve. It exist a connection between using Ordinary Least Squares regression (OLS) and quintile regression (QR). But as OLS model the relationship between a set of explanatory variables and the conditional mean of the response variable, QR extends the regression model to conditional quintiles of a response variable such as $10^{\text {th }}, 20^{\text {th }}$ or $90^{\text {th }}$ quintile. $\mathrm{QR}$ is useful when the rate of change in the conditional quintile, expressed by the regression coefficients, depends on the quintile. The main advantages of QR over OLS method have difference and do not enforce the assumption that socio-economic factors have exactly the same effects on every point of the food expenditure distribution. For this reason the $\mathrm{QR}$ is more appropriate. $\mathrm{QR}$ is a type of regression analyzed in statistics and econometrics.

\section{Analyses of the results}

The welfare in Albania till now is measured the objective poverty and assessment through consumption. The highest share of consumption goes for food (INSTAT, HBS 2016). The share of food consumption to total household 
expenditure is decreased from year to year (Table 1). According to Engel's law, by the income (consumption) increase the proportion that households spend for necessary goods decrease and they tend to spent more for non food products and luxury goods. The poor households or less developed countries tried to spend more for food and necessary products. In our model we have used as a first category the amounts going for food and non food includes the expenditures goes for utilities, education, durables or other non food products. The share related with non food products is low.

Table 1. Percentage of real consumption per capita by year

\begin{tabular}{|c|c|c|c|c|}
\hline & 2002 & 2005 & 2008 & 2012 \\
\hline Food & 64.5 & 59.2 & 57.7 & 58.4 \\
\hline Non-food & 19.4 & 24.5 & 22.7 & 20.0 \\
\hline Utilities & 12.6 & 12.7 & 15.2 & 17.6 \\
\hline Education & 2.3 & 2.7 & 3.8 & 3.4 \\
\hline Durables & 1.2 & 0.9 & 0.5 & 0.6 \\
\hline
\end{tabular}

Source: INSTAT, 2013 (LSMS 2002, 2005, 2008, 2012)

The definitions how to classify as necessary goods and as a luxury goods are not exactly definition of food and not food products. We have considered food and utilities are necessary goods, and non food and durables are classified as luxury commodities. The marginal budget share estimates reveals that for a one lek increase in the household budget, on average and ceteris paribus, expenditure on food commodities rises by 0.58 Lek, on non food commodities by 0.20 of a lek, on durable goods by 0.6 of a Lek and on utilities by 0.18 of a lek. The highest level of share food is for the Central region $(60.7 \%)$ and the lowest for Tirana.

Table 2: Share of consumption

\begin{tabular}{|c|c|c|c|c|c|}
\hline Region & Food & Non-food & Utilities & Education & Durables \\
\hline Coastal & 58.9 & 20.3 & 17.0 & 3.2 & 0.6 \\
\hline Central & 60.7 & 18.5 & 16.7 & 3.5 & 0.6 \\
\hline Mountain & 57.9 & 20.9 & 16.0 & 4.7 & 0.5 \\
\hline Tirana & 52.7 & 22.4 & 21.0 & 3.1 & 0.7 \\
\hline Total & 58.4 & 20.0 & 17.6 & 3.4 & 0.6 \\
\hline
\end{tabular}

Source: INSTAT (LSMS 2012)

From the first quartile to the highest, the food consumption increased and the share of food by total expenditure decreased. Inter quartile range of food consumption Q5/Q1 is 3.2 and the percentage of expenditures goes for food have a difference by 10 point percent Q5 from Q1. This shows lowest trend for rich people to spend for food products. 
Table 3: Per capita total consumption, food expenditures

\begin{tabular}{|c|c|c|}
\hline Food consumption quartile & $\begin{array}{c}\text { Per capita food } \\
\text { consumption }\end{array}$ & Share for food consumption \\
\hline First & 2679 & 63.8 \\
\hline Second & 3703 & 60.7 \\
\hline Third & 4569 & 58.2 \\
\hline Forth & 5796 & 56.3 \\
\hline Fifth & 8526 & 52.9 \\
\hline
\end{tabular}

Source: LSMS 2012

If we take to the consideration the segment of the poor population the food consumption may be different from non food consumption and also total income/consumption. This happen because the influence of the prices and other factors related with household composition and economic situation.

Table 4: Per capita total consumption, food and non food expenditures by regions

\begin{tabular}{|c|c|c|c|c|c|}
\hline \multirow{2}{*}{$\begin{array}{c}\text { Food consumption } \\
\text { quartile }\end{array}$} & \multicolumn{5}{|c|}{ Food consumption by regions } \\
\cline { 2 - 6 } & Costal & Central & Mountain & Tirana & \\
\hline First & 54.0 & 51.0 & 47.5 & 46.2 & 54.0 \\
\hline Second & 55.6 & 55.9 & 56.9 & 50.6 & 55.6 \\
\hline Third & 59.9 & 60.4 & 60.1 & 54.6 & 59.9 \\
\hline Forth & 61.7 & 63.7 & 64.4 & 55.0 & 61.7 \\
\hline Fifth & 68.6 & 65.8 & 67.9 & 58.5 & 68.6 \\
\hline
\end{tabular}

Source: LSMS 2012

\section{Results of Quintile regression}

We have analyzed the quintile regression of the food consumption pattern and non food expenditures by different quintiles. The food consumption in the first table (A1) is used as depended variable and in the second model is used the non food trend (A2). The influence of individuals being in different levels of the economic situation is different. We have analyzed a set of variables for different percentiles of food consumption.

Our model is a linear model like examples taking to the consideration before:

$Y_{i j}=\alpha_{0}+\alpha_{1} x_{1}+\alpha_{2} x_{2}+\ldots . .+\alpha_{k} x_{k}$

$\mathrm{Y}_{\mathrm{ij}}$ is depended variable linearly connected significantly by as set of influenced socio-economic variables. There are considered variables related with individuals like sex, being unemployed, education, health but also other variables related with gender or education of the head or the characteristics of the dwelling where the household live (Xk). The $\alpha \mathrm{k}$ are parameters.

The effect of influenced variables are estimated by breaking interval of quartiles equally length from 0.1 to 0.9 . So the model does not produce a coefficient for each variable but one coefficient for each variable and each quintile. The standard errors are obtained by bootstrap procedure with 200 replications. The difference in food can come by total expenditure/income or 
by other variables that are more related with non monetary deprivation. As is explained (Table A1) for each k explanatory variable, the composition effect Ck 90/10 shows the comparison of the estimated effects at the 10th percentile till to the highest percentile 90th. Table 5 shows the coefficients of all variables used as independent variable for each quartile. Later for each variable is constructing the graph of the trend by quintile (Figure A.1). The inequality is a considered figure (26.9\%, World Bank and Instat, 2016).

The total consumption, number of children, household condition and assets have a significant influence in almost every quintile. Having at least one unemployed person to the household influence significantly to the lowest quintile of the household expenditures but not to the highest one. The employed directly affect the household condition as a source of income but also indirectly to other factors that influence the poverty and the living condition. Education is a long time factors influencing the food level. Gender is an important variable for the higher level of the quartiles. The gender difference does not influence the lower levels of the food consumption. Variables related with household composition like number of children or household size are increased with the increased of quartiles. After a level of food the coefficients goes down. The household assets or the household conditions have an important influence to the food consumption. There have a significant increase of consumption by having good condition to the home. Being overcrowded influence the lowest quintile but the significance level decreased with the increase of economic position of the individuals (Table A.1).

The trends of the variables sometimes are different for food expenditures compared with non food expenditures (Figure A.1, A.2). The trend and the coefficients of total per capita consumption are different. The coefficients for the influence to the non food products are higher than 1 and significant at $1 \%$ level. The possibility of having unemployed person at home does not influence non food pattern. The gender of head has an opposite impact to non food trend compared with the food influence. It influences significantly the lower quintile but not the trend of the highest quintile. The impact of the education is expected to be high. Testing the impact of the education to non food expenditures does not is considerable from the perspective of statistical significance. This means that we escape from being extreme poor but for other expenditures are other most important variables. Health is an indicator that contributes to the risk of being poor (Bici and Mancellari, 2015). The variables related with household ownership, having different assets influence non food expenditures, especially for the highest quintile. The same influence has other variables related with household condition or having heating at home. It is argue that the poverty is not anymore a rural phenomenon. Still the difference between regions is visible and 
significant. The geographic variable is considered important for the poverty level, income and expenditures source. The values of the coefficients are different from the food trend. Being on the urban area decreased the non food expenditures for all quintile levels, opposite to the result on the first table (Table A1). Heating, dwelling condition and crowding have also a negative effect.

\section{Conclusion}

The highest share of total consumption of Albanian households goes for food products. The households in top of the expenditures tend to spend more on luxury products rather then food products. Expenditures for food play an important role for development countries. Trend on consumption for food have different trend for different levels of income/consumption showing existence of inequality for different household characteristics. During years the situation has changed and also the concept of deprivation but these deprivations still significantly influence the expenditures trend and household life. Underlying the factors that influence the food trend we can see the risking factors of possibility of being extreme poor (indirectly the first quintile). The method tried to measure also a beginning of the indirect function of expenditures measured through individual and household characteristic. The influence of the same factors to the trend of non food products the situation is different and can give us a view for the possibilities of different economically position individuals to the expenditures other than food. Employment and education play an important role for household wellbeing and expenditures structure. The dwelling conditions influence the non monetary wellbeing of the household. So we have non monetary indicators that have a high impact to expenditures and inequality.

\section{References:}

1. Ahmed et al., (2012), The Prevalence of Poverty and Inequality in South Sudan: The Case of Renk County, Department of Agricultural Economics, Faculty of Agriculture, University of Khartoum, Sudan.

2. Attanasio, O.P., Pistaferri, L., (2016), Consumption Inequality, Journal of Economic Perspectives, Volume 30, Number 2, Spring 2016, Pages 3-28.

3. Betti, G. (2000), Quadratics Engel Curves and household equivalence scale: the case of Italy 1985-1994, Department of Statistics, London School of Economics.

4. Bici, R., (2016), Analysis and interpretation of functional connectivity of per capita food consumption in Albania. 
5. Bici, R., Mancellari, A. (2015), Public expenditures allocation and non monetary dimensions of poverty: the case of Albania, International Journal of Research, Volume 4.

6. Damodar N Gujarati - 2004, Economics - Basic Econometrics McGraw-Hill, Fourth Edition

7. Dawoud, Seham D. Z. (2013), Econometric analysis of the changes in food consumption expenditure.

8. Instat (2013), Shqipëria: Trendi $i$ varfërisë, 2002-2005-2008-2012.

9. Koenker, R. and Hallock, K. (2001). Quantile Regression. Journal of Economic Perspectives, 15, 143-156

10. Leser, C.E.V. (1963). Forms of Engel Functions, Econometrica

11. You, J. (2003). Robust Estimation of Models of Engel Curves, Empirical Economics.

12. Working, H. 1943. Statistical Laws of Family Expenditure. Journal of the American Statistical Association.

13. World Bank, (2005), Chapter 3: Poverty lines:

14. http://siteresources.worldbank.org/PGLP/Resources/povertymanual_c h3.pdf.

15. World Bank and Instat, (2016), Profili I varferise dhe pabarazise ne Shqiperi, www.worldbank.org.

16. Web LSMS micro data: http://www.instat.gov.al/al/temat/kushtetsociale/anketa-e-matjes-s\%C3\%AB-nivelit-t\%C3\%ABjetes\%C3\%ABs/\#tab2

\section{Annex}

Table A.1: Food expenditures Quintile regression

\begin{tabular}{|c|c|c|c|c|c|c|c|c|c|}
\hline & \multicolumn{9}{|c|}{ Food quintile } \\
\hline & $\mathrm{q} 10$ & Q20 & Q30 & $\mathrm{Q} 40$ & Q50 & Q60 & Q70 & Q80 & Q90 \\
\hline lnrconsr & $0.730 * * *$ & $0.807 * * *$ & $0.842 * * *$ & $0.882 * * *$ & $0.904 * * *$ & $0.926 * * *$ & $0.949 * * *$ & $0.963 * * *$ & $0.970 * * *$ \\
\hline unemploye & $0.019+$ & $0.030 * *$ & $0.021 *$ & $0.019 *$ & 0.017 & $0.013+$ & 0.006 & 0.004 & 0.004 \\
\hline headfemale & 0.005 & 0.014 & 0.002 & 0.003 & 0.013 & 0.015 & 0.019 & $0.023^{*}$ & $0.043 * * *$ \\
\hline children & $0.039 * * *$ & $0.039 * * *$ & $0.032 * * *$ & $0.024 * * *$ & $0.019 * * *$ & $0.017 * *$ & $0.018 * * *$ & $0.012 *$ & $0.012 * *$ \\
\hline health & $0.015 *$ & $0.018^{*}$ & $0.021 * *$ & $0.021 * *$ & $0.013 * *$ & $0.016 * *$ & $0.013 * *$ & $0.009+$ & $0.006+$ \\
\hline Female & $-0.031+$ & $\begin{array}{c}- \\
0.031 * * *\end{array}$ & $-0.030 *$ & $-0.023 *$ & -0.017 & -0.016 & $-0.022 *$ & $-0.023 * *$ & $\begin{array}{c}- \\
0.037 * * *\end{array}$ \\
\hline schyear & $-0.004 *$ & $\begin{array}{c}- \\
0.005^{* * *}\end{array}$ & $\begin{array}{c}- \\
0.005^{* * *}\end{array}$ & $\begin{array}{c}- \\
0.005^{* * *}\end{array}$ & $0.005^{* * *}$ & $\begin{array}{c}- \\
0.004 * * *\end{array}$ & $\begin{array}{c}- \\
0.006 * * *\end{array}$ & $\begin{array}{c}- \\
0.005 * * *\end{array}$ & $-0.004 * *$ \\
\hline hhsize & $\begin{array}{c}- \\
0.091 * * *\end{array}$ & $\begin{array}{c}- \\
0.078 * * *\end{array}$ & $\begin{array}{c}- \\
0.066^{* * *} * \\
\end{array}$ & $\begin{array}{c}- \\
0.055^{* * *}\end{array}$ & $\begin{array}{c}- \\
0.046^{* * * *}\end{array}$ & $\begin{array}{c}- \\
0.041 * * *\end{array}$ & $\begin{array}{c}- \\
0.035^{* * *}\end{array}$ & $\begin{array}{c}- \\
0.027 * * *\end{array}$ & $\begin{array}{c}- \\
0.023 * * * \\
\end{array}$ \\
\hline computer & $\begin{array}{c}- \\
0.144 * * *\end{array}$ & $\begin{array}{c}- \\
0.129 * * *\end{array}$ & $\begin{array}{c}- \\
0.127 * * * \\
\end{array}$ & $\begin{array}{c}- \\
0.116^{* * *} \\
\end{array}$ & $\begin{array}{c}- \\
0.109 * * *\end{array}$ & $\begin{array}{c}- \\
0.097 * * *\end{array}$ & $\begin{array}{c}- \\
0.099 * * * \\
\end{array}$ & $\begin{array}{c}- \\
0.104 * * * \\
\end{array}$ & $\begin{array}{c}- \\
0.103 * * * \\
\end{array}$ \\
\hline refrigerator & $-0.097 *$ & $\begin{array}{c}- \\
0.094 * * *\end{array}$ & $\begin{array}{c}- \\
0.080^{* * *}\end{array}$ & $\begin{array}{c}- \\
0.085^{* * *}\end{array}$ & $\begin{array}{c}- \\
0.079 * * *\end{array}$ & $\begin{array}{c}- \\
0.074 * * *\end{array}$ & $\begin{array}{c}- \\
0.054 * * *\end{array}$ & $\begin{array}{c}- \\
0.052 * * *\end{array}$ & $\begin{array}{c}- \\
0.057 * * *\end{array}$ \\
\hline car & $\begin{array}{c}- \\
0.203 * * *\end{array}$ & $\begin{array}{c}- \\
0.180^{* * *}\end{array}$ & $\begin{array}{c}- \\
0.176^{* * *}\end{array}$ & $\begin{array}{c}- \\
0.157 * * * \\
\end{array}$ & $0.144^{-} * *$ & $0.139^{-} * * *$ & $\begin{array}{c}- \\
0.127^{*} * * \\
\end{array}$ & $\begin{array}{c}- \\
0.108^{* * *} \\
\end{array}$ & $0.114^{-} * * *$ \\
\hline
\end{tabular}




\begin{tabular}{|c|c|c|c|c|c|c|c|c|c|}
\hline Rent & $-0.073 *$ & -0.035 & $-0.056 *$ & -0.023 & $-0.048 * *$ & $-0.041 * *$ & $-0.048 * *$ & $-0.041 *$ & - \\
& & & & & & & $0.036 * * *$ \\
\hline urban & $0.056 * * *$ & $0.064 * * *$ & $0.063 * * *$ & $0.066 * * *$ & $0.059 * * *$ & $0.053 * * *$ & $0.045 * * *$ & $0.034 * * *$ & $0.028 * * *$ \\
\hline Noheating & $0.050 * *$ & $0.039 * *$ & $0.029 * *$ & $0.021 *$ & 0.010 & 0.004 & 0.003 & 0.004 & 0.003 \\
\hline dwellcondit & $0.084 * * *$ & $0.083 * * *$ & $0.070 * * *$ & $0.070 * * *$ & $0.074 * * *$ & $0.083 * * *$ & $0.084 * * *$ & $0.077 * * *$ & $0.065 * * *$ \\
\hline crowding & $0.065 * * *$ & $0.044+$ & $0.055 *$ & $0.043 *$ & $0.044 *$ & $0.038+$ & $0.025+$ & 0.023 & 0.013 \\
\hline cons & $1.824 * * *$ & $1.212 * * *$ & $0.951 * * *$ & $0.624 * * *$ & $0.458 * * *$ & $0.270 *$ & 0.115 & 0.042 & 0.056 \\
\hline
\end{tabular}

Table A5.2: Non food expenditures quintile regression

\begin{tabular}{|c|c|c|c|c|c|c|c|c|c|}
\hline & \multicolumn{9}{|c|}{ Non food quintiles } \\
\hline & $\mathrm{q} 10$ & Q20 & Q30 & $\mathrm{Q} 40$ & Q50 & Q60 & Q70 & Q80 & Q90 \\
\hline lnrconsr & $1.103 * * *$ & $1.084 * * *$ & $1.109 * * *$ & $1.127 * * *$ & $1.143 * * *$ & $1.146 * * *$ & $1.163 * * *$ & $1.170 * * *$ & $1.173 * * *$ \\
\hline unemploye & 0.006 & -0.003 & -0.005 & -0.009 & -0.016 & $-0.020+$ & -0.015 & $-0.024+$ & -0.018 \\
\hline headfemale & $-0.122 *$ & $-0.059 * *$ & $-0.043+$ & $-0.037 *$ & -0.002 & 0.001 & 0.011 & 0.004 & -0.009 \\
\hline Children & $\begin{array}{c}- \\
0.047 * * *\end{array}$ & $-0.024 *$ & $-0.030 * *$ & $\begin{array}{c}- \\
0.027 * * *\end{array}$ & $-0.027 * *$ & $\begin{array}{c}- \\
0.032 * * *\end{array}$ & $\begin{array}{c}- \\
0.036 * * *\end{array}$ & $\begin{array}{c}- \\
0.037 * * *\end{array}$ & $\begin{array}{c}- \\
0.032 * * *\end{array}$ \\
\hline Health & -0.014 & $-0.032 * *$ & $\begin{array}{c}- \\
0.027^{*} * * \\
\end{array}$ & $\begin{array}{c}- \\
0.027 * * * \\
\end{array}$ & $-0.024 * *$ & $\begin{array}{c}- \\
0.031 * * *\end{array}$ & $-0.025 * *$ & $-0.019 * *$ & $-0.013+$ \\
\hline Female & $0.112 * * *$ & $0.045 * *$ & $0.045^{*}$ & $0.027 *$ & 0.017 & 0.018 & $0.018 *$ & $0.019+$ & $0.023 * *$ \\
\hline Schyear & $0.015 * * *$ & $0.013 * * *$ & $0.012 * * *$ & $0.008 * * *$ & $0.007 * * *$ & $0.006 * * *$ & $0.006 * *$ & $0.004 * *$ & $0.003 *$ \\
\hline Hhsize & $0.084 * * *$ & $0.064 * * *$ & $0.073 * * *$ & $0.068 * * *$ & $0.070 * * *$ & $0.070 * * *$ & $0.072 * * *$ & $0.070 * * *$ & $0.064 * * *$ \\
\hline computer & $0.213 * * *$ & $0.177 * * *$ & $0.135 * * *$ & $0.116 * * *$ & $0.113 * * *$ & $0.102 * * *$ & $0.092 * * *$ & $0.085 * * *$ & $0.063 * * *$ \\
\hline refrigerator & $0.366 * *$ & $0.297 * * *$ & $0.240 * * *$ & $0.265 * * *$ & $0.233 * * *$ & $0.182 * * *$ & $0.171 * * *$ & $0.166 * * *$ & $0.124+$ \\
\hline Car & $0.266 * * *$ & $0.205^{* * *}$ & $0.181 * * *$ & $0.169 * * *$ & $0.161 * * *$ & $0.150 * * *$ & $0.132 * * *$ & $0.107 * * *$ & $0.096 * * *$ \\
\hline Rent & 0.116 & $0.077+$ & $0.082 *$ & $0.056+$ & $0.064 *$ & $0.050 *$ & $0.052^{*}$ & $0.042 *$ & $0.042+$ \\
\hline Urban & -0.094 & $\begin{array}{c}- \\
0.090^{* * *}\end{array}$ & $\begin{array}{c}- \\
0.098 * * * \\
\end{array}$ & $\begin{array}{c}- \\
0.100^{* * *}\end{array}$ & $\begin{array}{c}- \\
0.094 * * * \\
\end{array}$ & $\begin{array}{c}- \\
0.080^{* * * *}\end{array}$ & $\begin{array}{c}- \\
0.070 * * * \\
\end{array}$ & $\begin{array}{c}- \\
0.059 * * * \\
\end{array}$ & $\begin{array}{c}- \\
0.044 * * * \\
\end{array}$ \\
\hline Noheating & -0.024 & -0.022 & -0.017 & -0.025 & $-0.031 * *$ & $-0.038 * *$ & $-0.038 * *$ & $-0.049 * *$ & $-0.050 * *$ \\
\hline dwellcondit & -0.173 & $\begin{array}{c}- \\
0.176^{* * * *} \\
\end{array}$ & $\begin{array}{c}- \\
0.155^{* * * *}\end{array}$ & $\begin{array}{c}- \\
0.132^{*} * * \\
\end{array}$ & $\begin{array}{c}- \\
0.099 * * * \\
\end{array}$ & $\begin{array}{c}- \\
0.083 * * *\end{array}$ & $\begin{array}{c}- \\
0.075 * * * \\
\end{array}$ & $\begin{array}{c}- \\
0.064 * * *\end{array}$ & $\begin{array}{c}- \\
0.050^{* * *}\end{array}$ \\
\hline crowding & -0.066 & $-0.060+$ & $-0.066^{*}$ & $-0.071^{*}$ & $\begin{array}{c}- \\
0.086 * * *\end{array}$ & $-0.071 *$ & $\begin{array}{c}- \\
0.074 * * * \\
\end{array}$ & -0.037 & $-0.080 * *$ \\
\hline _cons & -2.891 & $\begin{array}{c}- \\
2.323 * * *\end{array}$ & $\begin{array}{c}- \\
2.381 * * * \\
\end{array}$ & $\begin{array}{c}- \\
2.417 * * * \\
\end{array}$ & $\begin{array}{c}- \\
2.493 * * * \\
\end{array}$ & $2.410^{-} * * *$ & $\begin{array}{c}- \\
2.495 * * * \\
\end{array}$ & $\begin{array}{c}- \\
2.465 * * * \\
\end{array}$ & $\begin{array}{c}- \\
2.362 * * *\end{array}$ \\
\hline
\end{tabular}


Figure A.1: Food consumption quintile by each factor

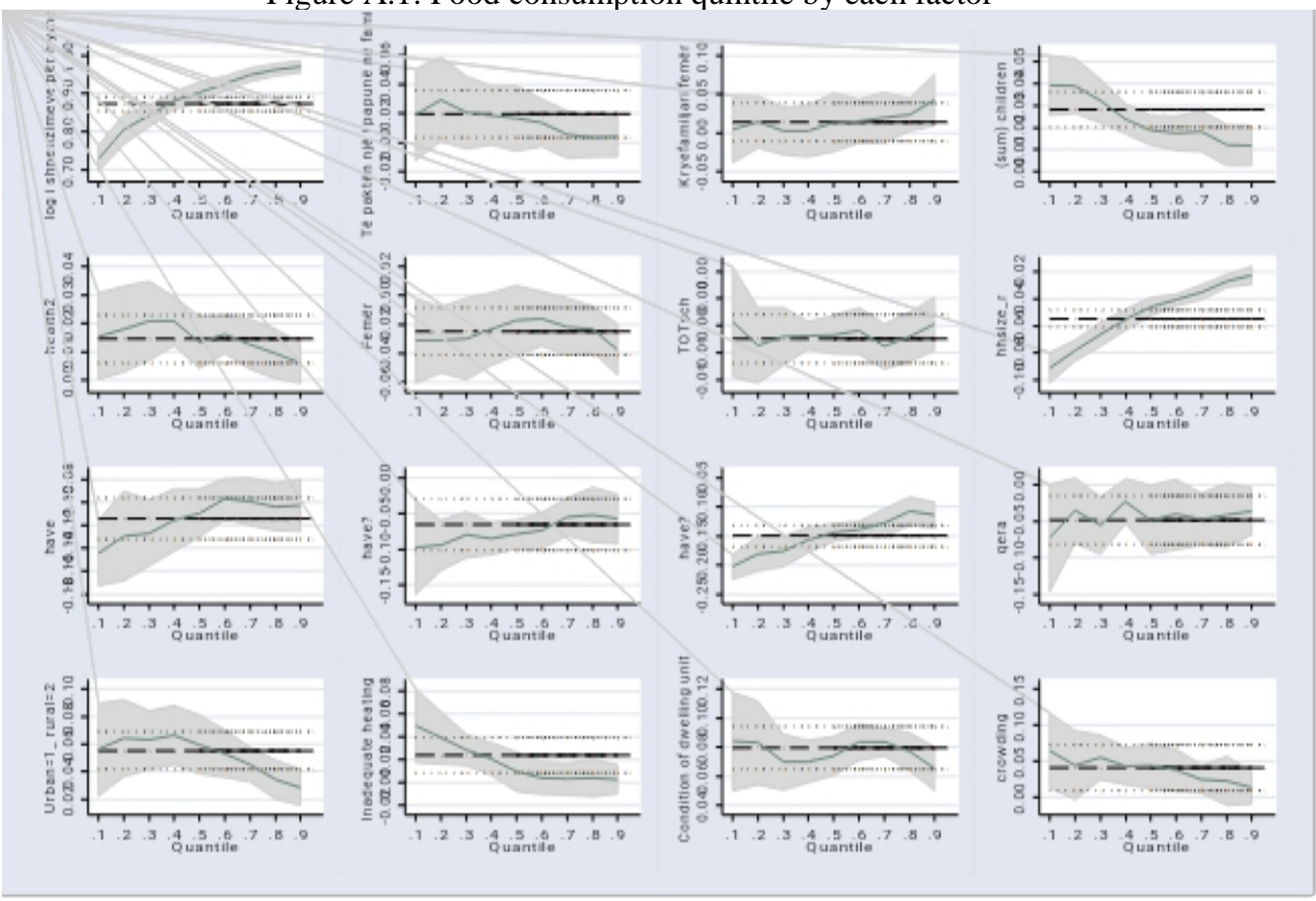

Figure A.2: Non food expenditures quintile
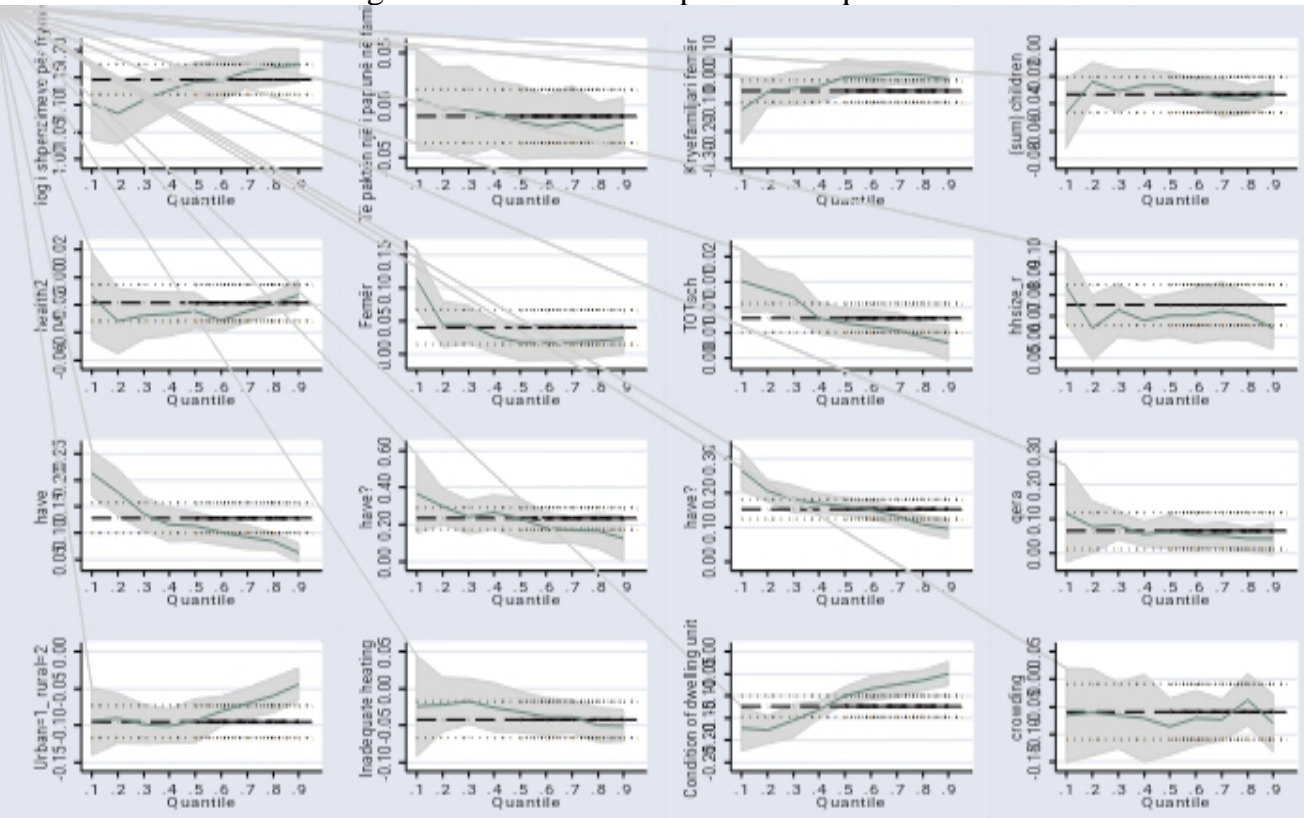